Article

\title{
Attitudes and Behaviours of Certified Winegrowers towards the Design and Implementation of Biodiversity Farming Strategies
}

\author{
Wendy McWilliam * (D) and Andreas Wesener (D) \\ School of Landscape Architecture, Faculty of Environment, Society and Design, Lincoln University, \\ Lincoln 7647, New Zealand; andreas.wesener@lincoln.ac.nz \\ * Correspondence: wendy.mcwilliam@lincoln.ac.nz; Tel.: +64-3-423-0477
}

Citation: McWilliam, W.; Wesener, A. Attitudes and Behaviours of Certified Winegrowers towards the Design and Implementation of Biodiversity Farming Strategies. Sustainability 2021, 13, 1083. https://doi.org/ $10.3390 /$ su13031083

Academic Editor: Duncan

B. Westbury

Received: 20 November 2020

Accepted: 18 January 2021

Published: 21 January 2021

Publisher's Note: MDPI stays neutral with regard to jurisdictional claims in published maps and institutional affiliations.

Copyright: (c) 2021 by the authors. Licensee MDPI, Basel, Switzerland. This article is an open access article distributed under the terms and conditions of the Creative Commons Attribution (CC BY) license (https:// creativecommons.org/licenses/by/ $4.0 /)$.

\begin{abstract}
Substantial environmental impacts and loss of resilience occurs with conventional vineyard designs characterized by monotonous specialized production. Studies support the restoration of green infrastructure (GI) and introduction of other production systems as promising biodiversity design strategies. However, little is known about the degree to which winegrowers are implementing them. We surveyed Willamette valley, Oregon, certified sustainable winegrowers as potential early adopters of innovative biodiversity design strategies. Results revealed growers were implementing up to 11 different types of GI components, providing them with up to 16 different ecosystem services, and six disservices. The GI was implemented at three spatial scales, with growers pursuing a sharing GI design strategy at fine scales, and a sharing and sparing strategy at intermediate and farm-wide scales. Only biodynamic certified farmers had implemented valued additional production systems. Growers can improve the implementation of their biodiversity GI designs by adopting an integrated multi-system whole farm design approach. Key enablers for grower implementation of GI and/or additional production systems included: (1) Grower awareness and value of strategy's ecosystem services and functions, (2) grower knowledge of their design and management, (3) certifier requirements for GI, (4) availability of land incapable of growing quality grapes, (5) availability of GI backup systems in case of failure, (6) low risk of regional pest outbreaks, (7) premium wine prices, and (8) strong grower environmental and cultural heritage ethics. Further research is required to identify effective ways to advance these enablers among growers, and within certification and government programmes, to improve the implementation of these strategies among growers.
\end{abstract}

Keywords: biodiversity farming strategies; vineyard; sustainability; implementation; green infrastructure; ecosystem services

\section{Introduction}

Historically, grape vines were often part of mixed production systems resulting in multiple income streams. Farms produced crops other than just grapes, such as animal products, and/or lumber [1], on farm areas whose biophysical conditions best suited their growth. They also had areas of vegetation, such as remnant forest, and riparian corridors, not directly related to production. However, more recently, many vineyard farms within industrialized countries removed this vegetation, and piped or channelized waterways, when these were viewed as impeding or reducing production. Furthermore, farms became specialized, only producing grapes and wine, with external inputs, such as fossil fuels, water, synthetic fertilizers, and pesticides [2] to offset limitations posed by imperfect growing conditions. Resulting vineyard landscapes are often biologically and visually homogenous [3], with wine grape vines, and little other vegetation, apart from cellar door landscaped areas (Figure 1). 


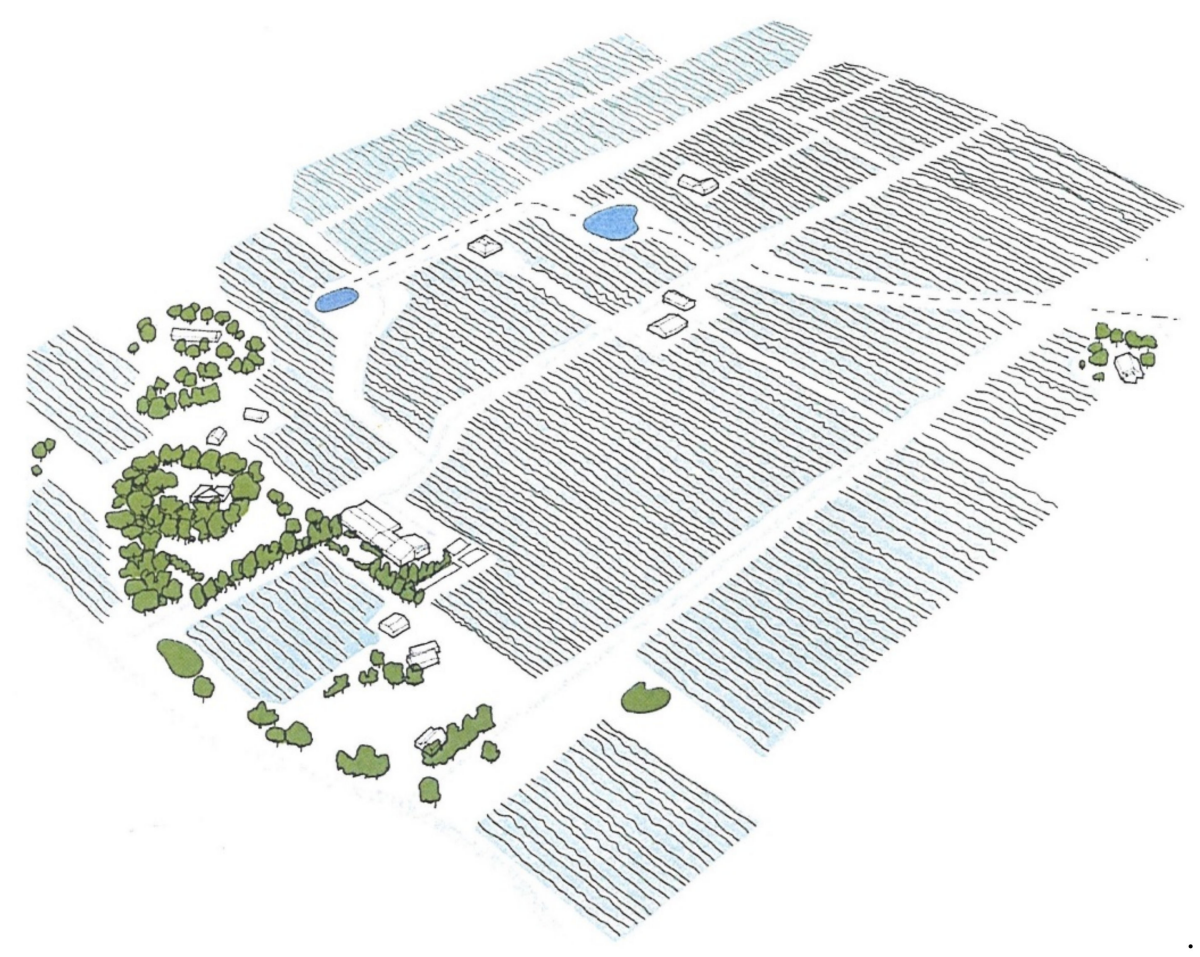

Figure 1. Conventionally designed homogenous vineyard farm.

Significant environmental impacts are associated with these designs, including water pollution [4] soil loss [5], soil pollution [6], and significant carbon emissions [7]. These designs have also led to losses in beneficial invertebrates [8], soil biota [9], and higher pest vulnerability [1]. In addition, they provide low support for indigenous biodiversity [10] and have low resilience to climate change, as ecosystems with low spatial and temporal variability have low adaptive capacity in face of disturbance [11].

Internationally, wine grape systems are shifting to more sustainable production practices [12]. Certified wine grape farmers may be helping to lead this shift [13], as certified farmers within many agricultural systems often stimulate farming innovation among their more conventional peers [14]. In part, this shift is being motivated by a desire to capture a growing market and price premiums for wines perceived as better for the environment [2,15], wine quality [10], and human health [16]. The literature identifies two main greening strategies for improving sustainability of conventionally design farms: Efficiency/substitution farming and biodiversity-based farming [17].

Efficiency/substitution farming strategies are most studied and are defined as those that seek to reduce impacts of concern to regulators by increasing input efficiencies and substituting components considered environmentally benign [17]. Many winegrowers are focusing on reducing environmentally harmful and potentially noxious synthetic inputs, particularly organic and biodynamic certified farmers [18]. In fact, organic certification practices in the United States, governed by the United States Department of Agriculture, focus on reducing or avoiding synthetic fertilizers and plant protection substances (e.g., pesticides and herbicides). Biodynamic certification, according to Demeter-USA [19], not only requires the reduction of these inputs, but discourages all external inputs outside the farm boundary, including those organic. It seeks to preserve, enhance, and integrate resources across a vineyard farm in support of balanced ecosystem health. It recommends using non-synthetic concoctions to improve soil and microbial health, and timing farm activities based on the phase and zodiacal constellation of the moon.

While studies support many of these practices, there is uncertainty about some of their environmental benefits within vineyards [20]. Supporting studies have demonstrated reductions in some externalities with their adoption, and improved microbial biomass and enzyme activity in soils, with the substitution of synthetic with organic fertilizers [21]. Oth- 
ers have demonstrated soil structure improvements, and increased microbial activity and fertility, with the application of animal manure and plant extracts to soils [22]. In addition, some have demonstrated reductions in carbon emissions with the substitution of motorized equipment with human labour [13], and with the reduced and altered use of nitrogenous fertilizers [23]. However, another study found no reduction in carbon emissions with the substitution of synthetic with organic fertilizers [7]. Furthermore, this strategy does not address some impacts, such as poor support for indigenous biodiversity, and low system resilience to economic and environmental stochastic events or climate change [11].

Fewer studies have examined the adoption of these strategies among growers. Studies suggest best practice is focused on reducing the use of harmful synthetic inputs; however, only a minority of growers in surveys had significantly reduced their use [24,25]. Key motivators included concern for grower/worker health [24,25], the presence of legislative policies requiring integrated pest management [24], and grower beliefs in their benefits for improving soil quality and ecosystem health. One study found that, to be motivated to implement this strategy, growers needed to be able to effectively signal to consumers that their practices not only improved environmental health, but the quality of their wine [25]. Barriers included grower disbelief in, or uncertainty about, the benefits of such practices (particularly with respect to pest control), environmental concerns about the use of copper (an organic substitute), and the financial risks associated with relying on alternatives to synthetic inputs [25].

Biodiversity-based farming strategies are much less studied [17]. They focus on not only mitigating environmental impacts of farming, but also on providing additional ecosystem services $[17,26]$. They may involve the addition of other production systems, or the conservation and restoration of ecosystem service providers (ESPs) on farms, the latter of which are defined as "component populations, species, guilds, food webs or habitats that provide ecosystem services" [27] (p. 469). As this research is concerned with the design and implementation of spatial aspects of ESPs within vineyards, we use the term green infrastructure (GI) when referring to them. The concept of GI is used in the fields of landscape architecture and landscape planning. It was first applied to urban landscapes and regions to highlight the essential role of vegetation and water-based natural, semi-natural, and artificial (ESP) networks in these landscapes for providing key ecosystem services in support of community health and well-being [28]. In wine-grape production systems, we define GI as multi-spatial scaled networks of natural, semi-natural or human-constructed/planted areas of non-vine vegetation, water elements, and other structures (e.g., nesting boxes), that provide key ecosystem services to winegrowers, communities, and markets.

There is a significant amount of scientific research in support of some components of green infrastructure and some of their ecosystem services, within vineyards. Cover crop GI components have been the focus. Inter-row cover crops reduce erosion and enhance soil carbon [29], and row cover crops can suppress weeds, retain moisture, enhance soil microbial activity [30], and can alter soil fertility [31]. Furthermore, inter-row crops, and particularly, vegetated buffer strips between vineyard blocks and waterways, can mitigate nitrate pollutants within surface and groundwater [32]. In addition, pest regulation services can be provided by row cover crops [30], inter-row cover crops [33], and semi-natural non-vine vegetation in and around vineyards, such as woodlands, hedgerows, grasslands, and shrubs $[34,35]$. However, other studies have also demonstrated cover crops can provide habitat for pests [36]. The amount and diversity of these types of GI (in addition to others, such as tree rows, individual trees, road and field margins, and farm buildings) both at local and landscape scales, can increase species richness and abundance [10,37]. Other production systems, such as vegetable crops, and residential gardens can also contribute heterogeneity, and therefore habitat diversity, to these landscapes [10]. While increasing heterogeneity in vineyard landscapes can also increase resilience to, or reduce the risk of, environmental disturbances, such as pest outbreaks, the transmission of pathogens, and buffering variations in climate [11], few studies have explored these relationships within vineyard landscapes. 
There are few studies regarding effective spatial designs of biodiversity strategies within vineyards. Studies within the field of landscape architecture have primarily focused on evaluating designs that conserve and enhance spatial designs in support of their cultural services, such as those enhancing their aesthetic experiences, and cultural heritage [38]. Other fields, such as conservation biology, have focused on identifying relationships between production systems and semi-natural vegetation that increase biodiversity in homogenous agricultural landscapes. Spatial strategies identified as sparing and sharing have been debated. In a sparing strategy, farmers concentrate land for nature conservation, leaving their remaining land for intensive production [39]. Proponents of this strategy often view nature and agricultural as incompatible, with nature conservation areas not contributing to agricultural production. They also argue that concentrating nature conservation leads larger areas, that are known to often support more species with larger populations than smaller areas [40]. However, externalities associated with the remaining productive land often continues unabated as it has no or little GI to provide mitigation.

A sharing strategy, on the other hand, incorporates smaller and more areas of GI into production systems, and can lead to more extensive production with fewer local environmental externalities [39]. Supporters of this strategy argue this GI can be designed to provide more ecosystem services than just enhanced biodiversity, such as those benefiting production (e.g., pest regulation or microclimate mitigation). Here, proponents view nature and agriculture as complementary. However, the smaller GI components may support fewer species with smaller populations more vulnerable to extirpation with an environmental stochastic event [41]. These two strategies are not mutually exclusive and can be implemented at different spatial scales within the same landscape [42].

There is less research on winegrower implementation of GI, or additional production systems. In terms of GI, cover crops, and their contribution to soil quality, have been the focus of studies. Few other types have been studied, or the multiple ecosystem services they provide vineyards [43]. Studies in Italy, Spain, and New Zealand indicate poor uptake of cover crops among growers $[24,44,45]$. In an Italian study, the adoption of grassed cover crops (the only GI mentioned by growers), was a low priority relative to efficiency/substitution practices, such as reducing synthetic pesticide use [24]. The key enabler for implementing cover crops in this study was a grower desire to improve soil quality. However, the study in Spain [44], which indicated similarly poor uptake, found that few growers were willing to implement cover crops which would reduce soil erosion, due to concern that cover crops would compete with vines for water, lack of knowledge regarding effective cover crops, and unwillingness to accept production decreases thought to be associated with cover crop adoption. The New Zealand study [45], focused on inter-row cover crops designed to provide beneficial insect management of vine pests, vine row weed suppression using indigenous plants, and hedgerows for microclimate control (particularly winds). The study found a similarly low rate of adoption among growers. The key barriers appeared to be uncertainty regarding their benefits, and the increased costs associated with their implementation and management. However, other studies conducted in France, and one in Spain, indicated most winegrowers implemented cover crops [46,47]. Growers implemented a variety of spatial strategies (e.g., both inter and row, row only, inter-row only, and a variety of patterns of cover crops alternating with bare soil), and management strategies (e.g., use of tillage, herbicides, rolling or mowing cover crops at different frequencies and times of the year). Higher coverage of cover crops within vineyards was correlated with higher wine quality (e.g., Protected Designation of Origin (PDO) wines in Europe), and certified organic wines, in addition to independent wineries with lower yields [47]. The New Zealand study also looked at the implementation of restored native vegetation in and around vineyard farms. Growers believed it provided habitat for indigenous species, but no other production or sales-related benefits. Implementation may have been enabled by partial external public and private company funding which reduced implementation costs for growers [45]. 
In this study we use long interviews with certified growers in the Willamette valley, Oregon to investigate their implementation of biodiversity farming strategies, involving incorporation of GI and additional production systems on their farms. Certified farmers are often leaders in advancing farming innovation among their more conventional peers [14]. We determined which GI types and production systems winegrowers were implementing and where. We also explored what ecosystem services and functions growers believed they provided, and whether and how they managed them. Furthermore, we identified enablers and barriers to their implementation. While the GI and other production systems identified in this study reflect the biophysical, socioeconomic, and cultural conditions of this wine region, and may not be appropriate for all wine regions, vineyards from other regions can learn from, and be inspired by, the grower perspectives, experiences and biodiversity designs uncovered in this study. Furthermore, the results of this study can assist scientists to identify future GI research which increase enablers and overcome barriers to winegrower biodiversity strategy implementation.

\section{Methods}

The study is based on a single case of specific and immediate interest as a revelatory case and does not seek generalization [48]. Vineyard farm system innovators in implementing biodiversity strategies, in the Willamette valley wine region in Oregon, United States (Figure 2), were targeted for interviews.

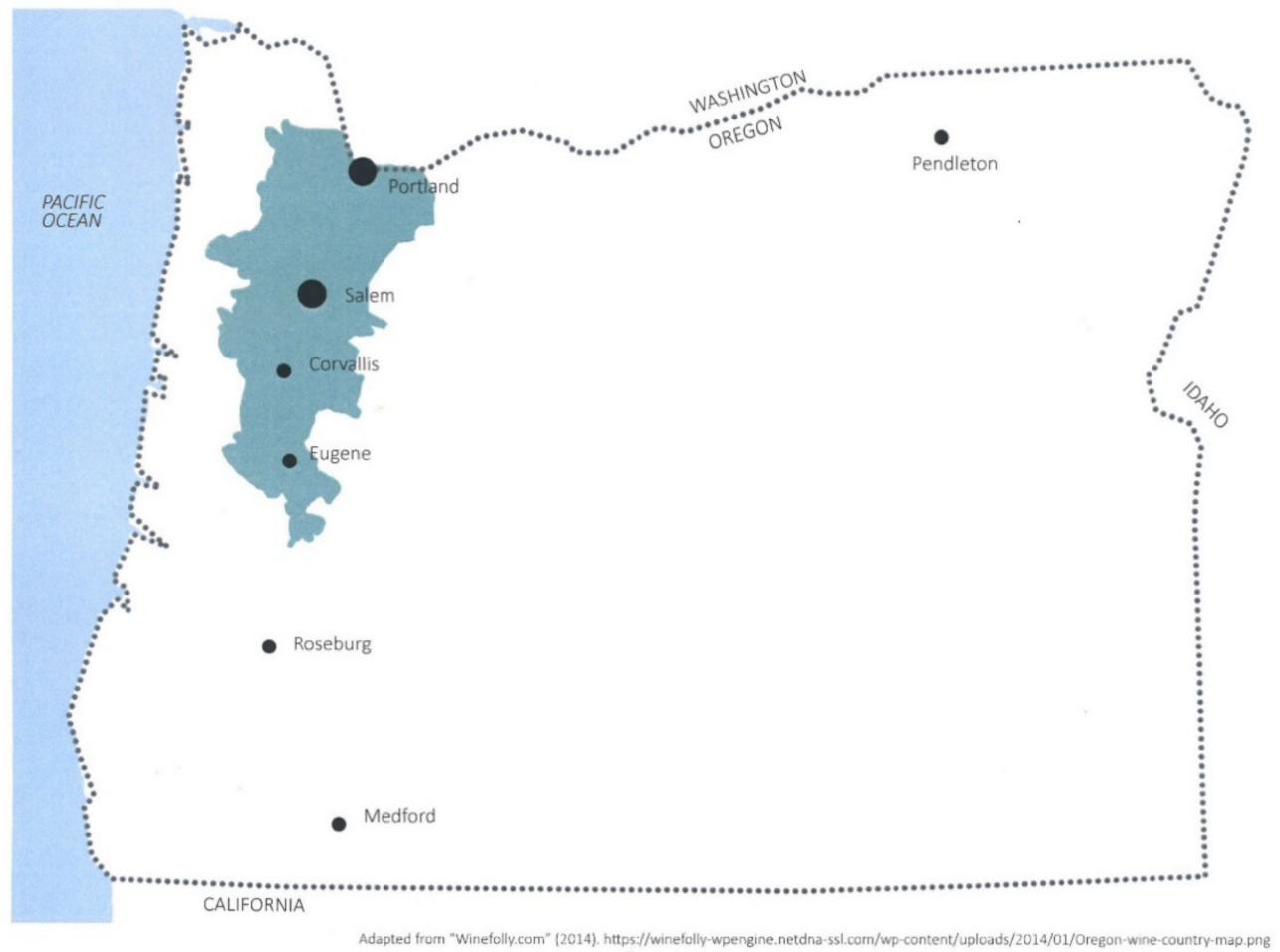

Figure 2. Willamette Valley wine region.

This is Oregon's leading wine region, renowned for its pinot noir wines. The region has a temperate warm to cool, often dry, summer, and wet winter climate (Csb type according to the Koppen climate classification system). Vineyards are mostly located on the lower hillsides of the Coast Range Mountains to the west and Cascade Range Mountains to the east, and not in the alluvial plain soils of the Willamette River. The hillsides were at one time characterized by oak savanna community (open woodlands characterised by Oregon white oak (Quercus breweri or garryanna var. breweri), Ponderosa pine (Pinus ponderosa) and prairie, supporting more than 200 species of wildlife [49]. However, less than one percent of the oak savanna remains, and is highly fragmented. Some of that remaining is being replaced 
by dense forests of Douglas fir (Pseudotsuga menziesii), Grand fir (Abies grandis), and Bigleaf maple (Acer macrophyllum). This is largely due to agricultural and urban development, lack of management, fire suppression, and lack of market for Oak savanna products [49]. Many of the hillsides where vineyards are located are steep, and soil cultivation has made soil erosion and degradation of surface water quality issues of concern [50].

Innovative growers were identified by the Low Impact Viticulture and Enology certified organization (LIVE) [51], which is not for profit, and was developed in 1997 by Willamette valley vineyard owners. It is third party verified by the International organization for the biological and integrated control of noxious animals and plants (IOBC). Certification requires vineyard farms and wineries to implement the most recent sciencebased best practices in support of quality fruit and wine production, sustained economic viability, minimum impacts of artificial system inputs, biological diversity, and soil fertility and stability [51]. This certification programme claims to determine best practices based on local biophysical conditions of their growers, rather than on the universal conditions [51]. This contrast with Organic certification, a national programme regulated by the U.S. Department of Agriculture (USDA), and Demeter biodynamic certification which is an international programme. Policies specific to the design of GI within LIVE's programme include a minimum of five percent of land "set aside" for nature conservation, whereas Demeter biodynamic requires a ten percent "set aside" [19,51]. Organic certification in the U.S. does not have any set aside requirements. In addition, both LIVE and Demeter biodynamic certifiers claim their practices should be applied to the whole vineyard farm, rather than just vineyard block components [19,51]. Organic certification does not specify where their practices apply on farms.

Vineyards were selected purposely, using a diverse case sampling method. This method is appropriate when the case selection intends to represent maximum variation in variables that might influence a phenomenon [52]. Eighteen vineyards were chosen that were a variety of sizes from 20 to 800 acres, with an average size of 241 acres. A variety of sizes were selected because farm size can influence productivity and economies of scale [53], grower willingness to reduce productivity to implement GI, and the availability of unproductive land for GI. Vineyards were also chosen to reflect a variety of certifications (Table 1). All farms were also Salmon safe certified, which is a not-for-profit Pacific west coastfocused organization that specifies best land management practices with respect to water quantity and quality in support of Pacific salmon (Oncorhynchus) and other indigenous spp. associated with waterways.

Table 1. Number of chosen vineyards by certification type.

\begin{tabular}{cc}
\hline Certification & Number of Chosen Vineyards \\
\hline $\begin{array}{c}\text { Low Impact Viticulture and Enology certified } \\
\text { organization (LIVE) }\end{array}$ & 10 \\
\hline USDA organic & 1 \\
\hline USDA organic plus Demeter biodynamic & 2 \\
\hline Demeter biodynamic plus LIVE & 1 \\
\hline $\begin{array}{c}\text { USDA organic plus Demeter biodynamic plus } \\
\text { LIVE }\end{array}$ & 2 \\
\hline $\begin{array}{c}\text { Adhering to Demeter biodynamic certified } \\
\text { practices, but no longer certified }\end{array}$ & 2 \\
\hline
\end{tabular}

Twenty-one key informants (farmers within the vineyards) were chosen non-randomly and purposely as those judged knowledgeable and sufficiently experienced in their respective roles in their vineyard. Following interviews, other informants within the vineyard were identified via the snowball method. Interviewees had an average 18 years' experience in their expertise. Selected interviewees held one or more of five roles on vineyards: (1) Vineyard owner, (2) vineyard manager, (3) winemaker, (4) vineyard consultant, and (5) 
ranch manager. To preserve their anonymity, interviewees are referenced according to a code (Table 2).

Table 2. Key to interviewee codes.

\begin{tabular}{cc}
\hline Role in Vineyard/Winery & Code \\
\hline Vineyard manager & V \\
\hline Vineyard manager, winemaker and owner & VWO \\
\hline Vineyard manager and owner & VO \\
\hline Vineyard manager, owner, and consultant & VOC \\
\hline Ranch manager (overseer of all production systems) & RM \\
\hline
\end{tabular}

Long interviews were conducted lasting on average $75 \mathrm{~min}$. The interview was designed and analysed according to Frankfort-Nachmias et al. [54]. The design was semistructured, focussing on three main questions: What GI and other production systems (beyond grape and wine production) key informants had on their farms, how they designed and managed them, and why they implemented them. Questions were open ended, allowing respondents to answer in their own words and express whatever they felt most important. If necessary, some more specific follow-up questions were added to avoid bias. For example, after key informants were asked about the GI on their farms, they were asked whether they had specific elements of GI. Terms familiar to growers were used in interviews to avoid misunderstanding. For example, terms such as green infrastructure, ecosystem services and disservices were not used as we could not assume growers were familiar with these concepts. Rather, we referred to GI as non-vine vegetation or water systems, and ecosystem services and disservices as benefits and drawbacks. Saturation of concepts was observed after 21 interviews.

Interviews were recorded, transcribed, and analysed using qualitative content analysis. The inductive coding of interview data allowed for the systematic development of categories (main themes and sub-themes of related information).

\section{Results}

\subsection{Green Infrastructure Components}

Interviewees indicated they had six main categories of GI on their farms: (1) Cover crop corridors, (2) invertebrate and pest patches, (3) nesting boxes and perches, (4) oak savanna or woodland patches and corridors, (5) hedgerows, and (6) entryway tree corridors, cellar door herbaceous and lawn Patches, and Ponds. The first three categories of GI were spatially associated with vineyard blocks. These were most frequently cited and valued as GI and were actively designed and managed in support of grape production. GI categories four and five were spatially focused on the edges of vineyard farms, or along waterways. These were also mentioned as valuable, largely for their nature conservation and branding services, but most growers did not actively design or manage them for these services, "The only area specifically designed is the vineyard which includes all the blocks of grapes and associated infrastructure. Anything outside receives only periodic mowing or no management (VWO1)." Lastly, category six GI types were spatially associated with cellar doors and wineries. Although when prompted growers said they were important for sales and branding, they were not volunteered as GI on farms. These GI were highly designed and managed but were not viewed by growers as operationally part of grape production areas.

\subsubsection{Cover Crop Corridors}

All interviewees grew cover crops between vine rows, with most alternating mown grass homogenous row crops with periodically cut diverse meadow row crops. Mown grass was perceived as being superior in preventing soil erosion, and for supporting tractor and human vine management, relative to meadow. It was also perceived to provided poorer 
habitat for small mammal pests (such as mice), reduced fire risk, and improved airflow to reduce risk of mildew. Meadow row crops were attributed complementary functions, providing habitat for beneficial insects, fungal and bacterial species which reduced grape vine pests, the most significant concern among interviewees. Furthermore, they regulated soil fertility and organic matter in support of vine growth, and therefore grape quality, "There we have clover growing, that's a nitrogen fixing plant. It impacts vine vigour, so you can grow plants to either take vigour out or put it back in (V3)."

Interviewees indicated a barrier to implementing meadow row crops was uncertainty regarding effective plant species for pest management. While accreditors provided guidance, evidence-based guidelines in support of consistent performance were lacking. Interviewees believed these services were provided; however, they did not monitor them, so were uncertain, "It's not something I've tried to measure. I think they work, but I'm basing this on intuition and romance (V3)." Many thought they might also harbour pest species, "It can be a host for beneficials sometimes during the year, but it can also harbour pests (V2)." However, many interviewees said their region did not have significant pest issues and therefore, they were not highly concerned about this possibility, "We don't have a lot of pests. The biggest thing in terms of insects would be mites and even they are not a big problem (VWO1)."

Uncertainty regarding how to manage cover crops through time was a significant barrier to implementation. Interviewees said they wanted a permanent cover crop, but where they cultivated it (e.g., to manage rigour), they had to re-establish it, which was expensive. In addition, some interviewees said meadow species taller than 18 inches interfered with insecticide application, impeded vine airflow increasing risk of mildew; and increased the risk of fire. In response, they cut meadows to below this height; however, were concerned this, and the application of pesticides, degraded habitat for, or killed, beneficial organisms; and reduced availability of seeds for meadow reestablishment, "If I could, I'd let everything go to seed and then I'd mow, but that's too late. By then, the stuff has grown too high above the vines, and then my sprays won't work (VWO4)."

\subsubsection{Beneficial Invertebrate or Pest Patches}

A minority of interviewees were also establishing small meadow patches between vineyard blocks, providing supplementary habitat to insectary corridors, and refuges for insect populations affected by management activities, "We've put five $3 \times 3$ insectaries on a 20-acre parcel. That's enough to support a high level of beneficial insects. In the vine rows, I always have something flowering, but not heavily. What I'm trying to do is build bridges there but encourage the bulk of the populations in the islands (VWO1)." Some also mentioned their aesthetic functions and habitat for bees, "They're beautiful to people walking in the vineyard, and we want to support native bees, even though they have nothing to do with the vineyard (RM1)."

Two interviewees said they had retained existing blackberry patches for pest species habitat. They believed patches played a role in attracting pests, so they would be less likely to occupy vines, "The blackberries provide homes for things like drosophila and the fruit flies that can get into the grapes. We'd rather have them go there than the grapes (VO1)."

While interviewees indicated they determined the species mix of meadow patches, their other characteristics, such as size, shape, or location of both types of inter-vine patches were determined, not by design, but by the characteristics of the land left over after grape blocks had been planted.

\subsubsection{Nesting Boxes and Perches}

Many interviewees said they had nesting boxes and perches, most mounted on posts within and between vineyard blocks, to encourage raptors to control passerine bird and small mammal pests, "Mice populations go through ebb and flow cycles and when they spike they can cause problems - same with gophers, moles, and voles. But, if you provide a place for a hawk to sit and hunt, they're doing the work for you, and you don't have to use poison (V4)." 


\subsubsection{Oak Savanna or Woodland Patches and Corridors}

Most interviewees said they had remnant oak savanna or woodland patches. LIVE and Demeter biodynamic certified interviewees indicated these areas were essential for meeting certification requirements for setting aside land for nature conservation (also referred to as ecological compensation zones). Qualifying land for set asides could not be associated with production, and these were among the few areas on farms that met that criteria. Certification allowed access to some markets and price premiums; however, interviewees argued it was not essential to wine sales.

Growers also said that many of these areas are not biophysically capable of producing quality wine grapes or supporting any other valued production system. The availability of these unproductive areas enabled larger farms to accept the loss of these lands from wine grape production. Small vineyard farms were largely growing quality grapes on most of their land, and the lack of unproductive grape land was a significant barrier to GI implementation, "You're giving up land that could be farmed and profitable (V3)." To avoid losing productive land, and still meet certification requirements, one grower with a small vineyard said he leased a neighbour's woodland patch to meet set aside requirements.

Conservation of these areas was also enabled by owners who believed these seminatural areas were important contributors to the cultural heritage of their landscape, and valued nature conservation above maximizing production. These values were evidenced by growers who conserved oak savanna or woodlands on land capable of growing quality wine grapes, "That forest over there would make a beautiful site for wine grapes, but it won't be because the owner is conservation minded (V1)."

All growers said the key ecosystem service of these areas was to provide habitat for "nature conservation." Most argued patches did not benefit their vineyard production system, although a few growers argued they were important for maintaining low levels of pest outbreaks in their wine region, "Your biodiverse areas provide crucial habitat for animals that will end up doing you favours. You get outbreaks of pests in a vacuum. Where the ecosystem functions as a whole, you're less likely to see outbreaks (V3)." One of these interviewees said the number of conventionally designed vineyards was increasing in the region, and she was concerned that the resulting loss of GI, in addition to impacts of climate change, would result in increased pest outbreaks, "With changing climate, I am concerned that pest types and numbers may change as is being experienced in France. We are now seeing more pests with more conventionally managed vineyards going into the valley (VWO1)."

Many growers also said these areas were key to the branding of their wine, and the wines within the Willamette valley wine region, "It's part of our story-that we're working hard to be as sustainable as possible - so the land we're farming on is in production for as long as possible. Brand Oregon means quality, and then environmentally conscious, a lack of greed, sense of place and stewardship (V1)."

Many growers who had waterways on their properties had conserved woodlands, along with other types of semi-natural vegetation, within their riparian corridors. They said they were important for mitigating negative environmental impacts of their production practices (e.g., use of pesticides) on water quality within their catchments. They followed Salmon safe certification requirements in their design, "This is a non-fish bearing stream, but it does feed into our fish bearing waters. We maintain a buffer-it's probably 150 feet and no spray (VWO1)." A secondary ecosystem service provided by these areas was nature conservation, particularly Pacific salmon (Oncorhynchus spp.). Salmon safe certification requirements for buffers, and guidance on their design, including widths, were key enablers for their implementation. However, some interviewees used at least part of their buffers for tractor turnarounds, which negatively affected their nature conservation functions, "In some cases you need 30 to 35 feet between end of row and fence to turn around your tractors during harvest, so there's a good reason to have a buffer strip at the end of rows (VWO1). Tractors are going to tear that (the buffer) up pretty badly (V1)."

Interviewees said disservices of woodlands included the provision of habitat for small pest mammals (e.g., voles, moles, and mice) which eat grapes and burrow holes in 
vineyard blocks. They said their woodlands also provided habitat for pest birds; however, most believed these would arrive regardless of their woodland, because of the amount of woodland in their landscape. They indicated they had effective methods for controlling them, "The flocks would still come, but they do like to perch in my woods. We have noisemakers, we have these propane canons, and we have shotguns (VWO3)."

Most interviewees indicated they did not design these areas (e.g., position them, shape them, or choose vegetation communities) to mitigate impacts on water quality within streams, or to support specific indigenous vegetation communities, or wildlife guilds. Their location and designs were largely determined by the biophysical characteristics of land incapable of producing quality wine grapes, or other forms of valued production. While a minority of interviewees were restoring indigenous vegetation species in their oak savanna or woodland, most were not managing these areas beyond removing what they viewed as noxious weeds, like Himalayan blackberry (Rubus armeniacus). A few of these interviewees (primarily Demeter biodynamic farmers) used animals to control it, rather than pesticides, which might run off into waterways, "We have the goats primarily to eat blackberry. Then we bring the pigs in to root it up (VOC1)."

\subsubsection{Hedgerows}

Many interviewees indicated they had boundary hedgerows. They said they did not provide any production service but, rather, aesthetic services in support of sales and branding, "They're not so much necessary in what I'm doing, but they look nice (VO7)." Some said they also provided cultural heritage services, containing remnant oaks from the previous oak savanna, or fruit trees from historic orchards. However, a few said their hedgerows had been removed by previous landowners to maximize grape yields, "We don't have too many of those left. That was a period of our history when maximizing production was paramount (VO3)." However, they did not have plans to replace them as they did not think they provided enough benefit to offset restoration and management costs.

A small minority believed their hedgerows provided beneficial insect habitat and pointed out the importance of jointly designing and managing these functions with neighbours sharing boundaries, "On those fence lines I've planted things like the native Lonicera, and a couple of insectary vines. Last year the neighbour sprayed them. But they were apologetic, replaced the plants, and now we have more of an understanding (VWO1)."

Again, most interviewees said they did not design, or manage their hedgerows in support of ecosystem services, such as pest regulation, nature conservation, or cultural heritage conservation. However, many said they managed them to limit their competition for resources with adjacent wine grapes. For example, they removed large trees, and pruned their hedgerows to reduce their rigour, and to enable vine management, "We have volunteer prunus and apple trees, and tonnes of native fruiting shrubs, but no large trees (VWO1)."

\subsubsection{Entryway Tree Corridors, Cellar Door Herbaceous Borders and Lawns, and Ponds}

While none of the interviewees mentioned these types of GI when asked whether they had non-vine vegetation or water systems on their properties, all interviewees had highly managed ornamental borders, lawns, and trees in and around cellar doors, and entryways. Characterised by mostly exotic and ornamental species, these areas of GI were the only ones on farms that appeared to be professionally designed by landscape architects. They were also highly managed. When asked, growers said they were important for the branding and sale of their wine. This was particularly true among interviewees having vineyards that sold a significant amount of their wine directly to consumers.

A few interviewees had human-designed irrigation and/or water supply ponds associated with their cellar doors and wineries. In addition to these functions, they provided fire regulation services, and contributed to cellar door aesthetics. These were not connected to waterways and were intensively managed to maintain their irrigation, water supply, and fire regulation functions through dredging. Most were artificially created and were not 
natural looking in appearance. For example, many had mown grass to the water's edge, and little indigenous, or natural-looking riparian vegetation.

\subsection{Green Infrastructure Networks}

Only one interviewee said she had implemented a GI network of components. She had a degree in ecology and had designed a beneficial invertebrate network consisting of inter vine row meadow cover crops and insectary patches, "We've put five $3 \times 3$ insectaries on a 20-acre parcel. That's enough to support a high level of beneficial insects. In the vine rows, I always have something flowering, but not heavily. What I'm trying to do is build bridges there but encourage the bulk of the populations in the islands (VWO1)."

She argued that a system, or network, approach to designing this GI was essential for maintaining beneficial invertebrate populations through time in face of impacts from vineyard management activities.

While a minority of interviewees mentioned they sought to apply a whole farm approach to implementing their farm practices (as is promoted by both LIVE and Demeter biodynamic certification), they were uncertain about what this meant for designing their GI. One interviewee indicated he was aware that a whole farm GI design approach, rather than a component approach, was necessary to enhance biodiversity in his vineyard, but did not mention such a design approach was important to support other GI services. He also suggested he was unsure about the GI systems he had on his farm. He said he first had to hire an external consultant to conduct a GI survey before he could arrive at a farmwide design, "We're going for a whole farm audit on the property and then coming up with a comprehensive plan to increase biodiversity (V4)."

Some interviewees indicated barriers to integrated GI design were accreditation set aside rules that assumed only some elements of vineyard GI provided nature conservation, e.g., woodlands and woodland corridors. They argued criteria for what constituted set asides seemed arbitrary, with qualifying elements identified more by their lack of association with production systems (which appeared to include cellar door and residential landscapes), then their contribution to nature conservation (such as providing habitat for indigenous species). They argued they had other areas of GI that may play a role in supporting nature conservation on their farms, but these did not qualify, "that's yard and it doesn't matter what you do with it, they (accreditors) still don't consider it to be part of a compensation zone (VWO2)."

A few interviewees mentioned they were interested in working with neighbouring farms, especially other vineyards, to develop connected GI "set aside" networks to better support nature conservation at coarser spatial scales, as well as to ensure long-term pest control services and general ecosystem resilience in their landscape, "We have neighbours with a vineyard. We've talked about ways that we can work together (VO2)." To enable this integration, one interviewee suggested the development of a new accreditation programme applied to all farm systems, focused solely on conserving, and restoring ecological compensation areas across the landscape, "We're working on breaking that piece of certification off and shopping it around to other types of farms (VWO2)."

\subsection{Non-Grape and Non-Wine Production Systems}

Most vineyards were following one or more of the following economic and environmental resiliency strategies: (1) Producing multiple wine grape varieties according to differing biophysical conditions across their vineyards, (2) harvesting or purchasing wine grapes from multiple vineyards (including from other growers), (3) producing multiple wine products for different markets, (4) pursuing external employment and/or (5) leasing land incapable of growing quality grapes to neighbouring farmers. However, few farmers focused on incorporating significant areas of non-vine production or agri-tourism. Only one grower mentioned concern for the impacts of climate change, or the need for increased resiliency in face of either economic or environmental stochastic events as reasons for their strategies. 
All interviewees said they were uninterested in growing other products than grapes on land suitable for high quality grape production, indicating this was the most profitable land use. Most strongly identified themselves as producers of high-quality grapes and wine, and not of other products or services, "I produce wine grapes and am a winemaker. I don't do animal husbandry (VO5)."

Only one farmer said he was interested in growing non-shading dwarf fruit trees among his grape vines, arguing this may increase vine health and vineyard aesthetics. However, he expressed uncertainty about how these trees might be incorporated without reducing his profitability per hectare, "It probably would take up more acreage for the same amount of grapes, so then you have additional land costs as spacing of vine rows would have to increase (V3)."

Larger vineyards which had significant areas of land unsuitable for quality grape production were not interested in producing poorer qualities of grapes on these lands, "If you paid for a piece of ground in a premium wine growing region, your goal is to make the best wine you can off a piece of ground. I don't want to represent anything less (VWO1)." They indicated this was a point of difference between them and conventional winegrowers who maximized grape and wine yields, no matter their quality, "Sure you want yield, but that's not the main driver for us. However, most vineyards are more yield driven (VWO3)." Most of these interviewees said they used a significant proportion of land incapable of producing quality grapes as lawn or meadow to enhance cellar door aesthetic experience in support of wine branding and sales. Some interviewees also leased areas (especially those not associated with cellar doors), to neighbouring farmers who produced hay or grass seed. A few interviewees, however, said they would not renew these leases as neighbouring farmer practices were not compliant with certification which applied across their farms, 'We're going to need to figure out how we're going to maintain these low grounds because LIVE certification is whole property, not just vineyard. You can't have a grass seed farmer spraying certain chemicals (OV1)." A minority of interviewees were producing other products within these areas, such as lumber or Christmas trees. However, they said they lacked the time and knowledge to manage and harvest them, "We've never worked on it because we never had the time to do it, and it really takes somebody who knows how to manage it and to do it properly, like a forester (V3)."

Among those having larger vineyards were the biodynamic farmers. They were the only interviewees who indicated they valued other production systems on their farms, but mostly for their support for their grape and wine production systems. Vineyard farm managers identified themselves as ranch managers as they managed all their production systems rather than just their vineyards, "My title has a distinction of ranch manager rather than vineyard manager because we do a lot of other things here (RM1)." They said certification required them to design whole farm ecosystems, not just vineyards and winery production systems. While the production of grapes and wine are the primary systems in terms of profitability, their goal was to produce as many of the products and services in support of these systems within the boundaries of their land as possible. Interviewees indicated their multiple production systems provided many benefits, including allowing them to limit use of fossil fuels, waste and other inputs leading to environmental impacts, "We have the organic grain growing on one side, a livestock element, a vegetable farm, and an orchard. The farm uses elements from one part of the farm to support others, allowing us to use the downstream products in a useful way rather than shipping them off the property as waste (RM1)." Their multiple production systems also allowed them to tell a unique story in support of wine sales. Furthermore, interviewees said their staff enjoyed the additional food products and year-round, instead of seasonal, employment. However, none of the additional production systems contributed significantly to farm profitability, as these vineyards did not sell products other than wine, externally.

Smaller vineyards indicated they lacked space for incorporating other productions systems. Given the high price they paid for their land, they said they could not afford to produce products less profitable than wine grapes and wine, "It's all vineyard suited land and we bought it already planted so we paid for the value of there being vines. Tearing them out means turning land worth $\$ 100,000$ to land worth $\$ 3000$ (VWO2)." 


\section{Discussion}

\subsection{GI Types, Spatial Design Strategies, and Their Ecosystem Services and Disservices}

The results indicate that these certified farmers not only implemented substitution/efficiency strategies to reduce their environmental impacts and risk of pest infestations, but also pursued biodiversity strategies, particularly through the retention, but infrequently restoration, of GI. However, only biodynamic farmers pursued biodiversity strategies that incorporated significant areas of other production systems.

While the amount and types of GI implemented by individual vineyard farms varied, as a group, interviewees incorporated eleven different GI types. Although growers mentioned six different disservices of their GI, these were outnumbered by their sixteen services, and most growers did not view these disservices as significant barriers to implementation. Further research is required to determine how widespread these GI are implemented by other certified and conventional growers in the region.

Growers are inadvertently pursuing a GI sharing design strategy at fine spatial scales (i.e., within vine and cellar door/winery blocks), and both sharing and sparing design strategies at coarser spatial scales (i.e., the between blocks scale and farm wide scale). Most of their GI types were designed as sharing GI, providing production and/or sales related services to growers. GI types providing largely nature conservation services, such as oak savanna and woodland patches and corridors were implemented largely as sparing GI (Table 3).

Table 3. Green infrastructure (GI) types, spatial design strategies and their ecosystem services and disserves by spatial scale.

\begin{tabular}{|c|c|c|c|}
\hline \multirow[b]{2}{*}{ GI Type by Spatial Scale } & \multicolumn{3}{|l|}{ Strategy } \\
\hline & $\begin{array}{c}\text { Sharing } \\
\text { Ecosystem Services/ } \\
\text { Benefits }\end{array}$ & $\begin{array}{l}\text { Sparing } \\
\text { Ecosystem } \\
\text { Services/ } \\
\text { Benefits }\end{array}$ & $\begin{array}{l}\text { Ecosystem Disservices/ } \\
\text { Drawbacks }\end{array}$ \\
\hline \multicolumn{4}{|c|}{ Within vine block scale } \\
\hline $\begin{array}{l}\text { Mown grass cover crop } \\
\text { corridors }\end{array}$ & $\begin{array}{c}\text { Erosion control, } \\
\text { Facilitates tractor use, } \\
\text { Aesthetic services (tidy/care) }\end{array}$ & & \\
\hline Meadow cover crop corridors & $\begin{array}{c}\text { Erosion control, } \\
\text { Pest regulation (beneficial organism } \\
\text { habitat-insects/fungi), } \\
\text { Soil fertility, } \\
\text { Soil organic matter, } \\
\text { Provisioning (improved grape quality), } \\
\text { Aesthetic services (colour when } \\
\text { flowering), } \\
\text { Enhanced sales/branding, } \\
\text { Feelings of identity/Pride }\end{array}$ & & $\begin{array}{c}\text { Pest habitat, } \\
\text { Increased fire risk, } \\
\text { Impedes airflow/mildew, } \\
\text { Impedes vine management, } \\
\text { Reduces aesthetic services } \\
\text { (messy when not blooming) }\end{array}$ \\
\hline \multicolumn{4}{|c|}{ Within cellar door/winery block (entryway/cellar door/winery) scale } \\
\hline Tree rows & $\begin{array}{c}\text { Aesthetic services } \\
\text { Improved branding/sales }\end{array}$ & & \\
\hline $\begin{array}{c}\text { Cellar door and winery } \\
\text { individual trees, herbaceous } \\
\text { borders and lawns }\end{array}$ & $\begin{array}{l}\text { Aesthetic services (colourful/tidy), } \\
\text { Improved branding/sales }\end{array}$ & & \\
\hline Cellar door ponds & $\begin{array}{c}\text { Irrigation, } \\
\text { Water supply, } \\
\text { Fire regulation, } \\
\text { Aesthetic services } \\
\text { Improved branding/sales }\end{array}$ & & \\
\hline
\end{tabular}


Table 3. Cont

\begin{tabular}{|c|c|c|c|}
\hline \multirow[b]{2}{*}{ GI Type by Spatial Scale } & \multicolumn{3}{|l|}{ Strategy } \\
\hline & $\begin{array}{l}\text { Sharing } \\
\text { Ecosystem Services/ } \\
\text { Benefits }\end{array}$ & $\begin{array}{l}\text { Sparing } \\
\text { Ecosystem } \\
\text { Services/ } \\
\text { Benefits }\end{array}$ & $\begin{array}{l}\text { Ecosystem Disservices/ } \\
\text { Drawbacks }\end{array}$ \\
\hline \multicolumn{4}{|c|}{ Between vine blocks and/or vine blocks and cellar door/winery block scale } \\
\hline Insectary patches & $\begin{array}{l}\text { Pest regulation (insects), } \\
\text { Aesthetic services (colour) }\end{array}$ & $\begin{array}{l}\text { Nature conservation } \\
\text { (bees) }\end{array}$ & $\begin{array}{c}\text { Pest habitat, } \\
\text { Increases fire risk, } \\
\text { Reduces aesthetic services } \\
\text { (messy when not blooming) }\end{array}$ \\
\hline $\begin{array}{l}\text { Oak savanna or woodland } \\
\text { patches (no waterway) }\end{array}$ & $\begin{array}{l}\text { Aesthetic services (Regional) } \\
\text { Enhanced sales/Branding, } \\
\text { Certification benefits (market entry; } \\
\text { sense of community; guidance), } \\
\text { Feelings of identity/Pride }\end{array}$ & $\begin{array}{l}\text { Nature conservation } \\
\quad \text { (in general) }\end{array}$ & $\begin{array}{l}\text { Pest habitat (small } \\
\text { mammals/birds) }\end{array}$ \\
\hline Nesting boxes/perches & Pest regulation (small mammals/birds) & & \\
\hline \multicolumn{4}{|c|}{ Vineyard farm scale } \\
\hline $\begin{array}{c}\text { Woodland corridors (where a } \\
\text { waterway) }\end{array}$ & $\begin{array}{c}\text { Aesthetic services (Regional), } \\
\text { Enhanced sales/branding, } \\
\text { Certification (market entry; sense of } \\
\text { community; best practice guidance), } \\
\text { Feelings identity/Pride }\end{array}$ & $\begin{array}{l}\text { Nature conservation, } \\
\text { Surface water quality } \\
\text { regulation }\end{array}$ & Pest habitat \\
\hline Vegetated Buffer corridors & $\begin{array}{l}\text { Certification (market entry; sense of } \\
\text { community; best practice guidance), } \\
\text { Feelings identity/pride }\end{array}$ & $\begin{array}{l}\text { Nature conservation, } \\
\text { Surface water quality } \\
\text { regulation (where a } \\
\text { waterway) }\end{array}$ & \\
\hline Hedgerows & $\begin{array}{l}\text { Cultural heritage, } \\
\text { Aesthetic services (local green frame), } \\
\text { Enhanced sales/branding, } \\
\text { Pest regulation }\end{array}$ & & $\begin{array}{l}\text { Vine resource competition, } \\
\text { Impedes vine management }\end{array}$ \\
\hline $\begin{array}{c}\text { Total services/disservices all } \\
\text { scales }\end{array}$ & 14 & 2 & 6 \\
\hline
\end{tabular}

\subsection{GI Networks and Whole Farm Design Approaches}

Both LIVE and Demeter biodynamic certification programmes stated they support a whole farm approach to implementing their farming practices [19,51]. This approach should also be applied to the implementation of across farms, as this research indicates that for growers many of their GI types are integral to their production or sales systems. Despite this, the concept of growers actively designing their GI across their farms, to achieve targeted ecosystem services, has yet to be embraced by growers. This is evidenced by only one interviewee that recognized the value of a systems or network approach to pest regulation services within her vineyard. All other forms of GI were implemented as separate components (e.g., implementing only cover crops to provide beneficial insect services in support of pest regulation). Most scientific studies focus on individual components of GI and their individual services within agricultural systems [17], including vineyards [20]. Until now, the multiple services provided by vineyards, including their green infrastructure systems, across vineyards, have received little study [43], and more is needed to stimulate this perspective among growers to encourage GI systems implementation.

Notably, Demeter biodynamic farmers are implementing their whole farm approach through the incorporation of multiple production systems within their farm boundary, rather than through the implementation of multiple GI networks across their vineyard farms. This is largely done to avoid external artificial system inputs. While these farms 
may succeed in reducing external system inputs through this approach, it may to lead to their isolation within their vineyard landscapes. There are many potential economic and ecological benefits associated with integrated farm systems, not just with neighbouring farms, but with farms across regions landscapes [55]. In terms of GI systems, some ecosystem services and functions can only be achieved at spatial scales courser than an individual farm. For example, a catchment-wide approach is needed to effectively design for high surface water quality in support of Pacific salmon, and a landscape scaled approach is often needed to provide habitat networks in support of species of conservation concern. Regional branding also requires a courser scaled design approach. Achieving these courser scale design goals requires the involvement of neighbouring landowners, local communities and regional governments in farm decision making $[17,26]$. Key steps toward this integrated approach are: (1) The design of GI as integrated whole farm networks (Figure 3), and (2) working with immediate neighbours to extend key GI networks onto adjacent properties. Figure 3 provides an illustration of how the conventional vineyard farm depicted in Figure 1 might be transformed into a more sustainable and resilient biodiversitybased vineyard farm through the integration of the GI components and networks identified in this research.

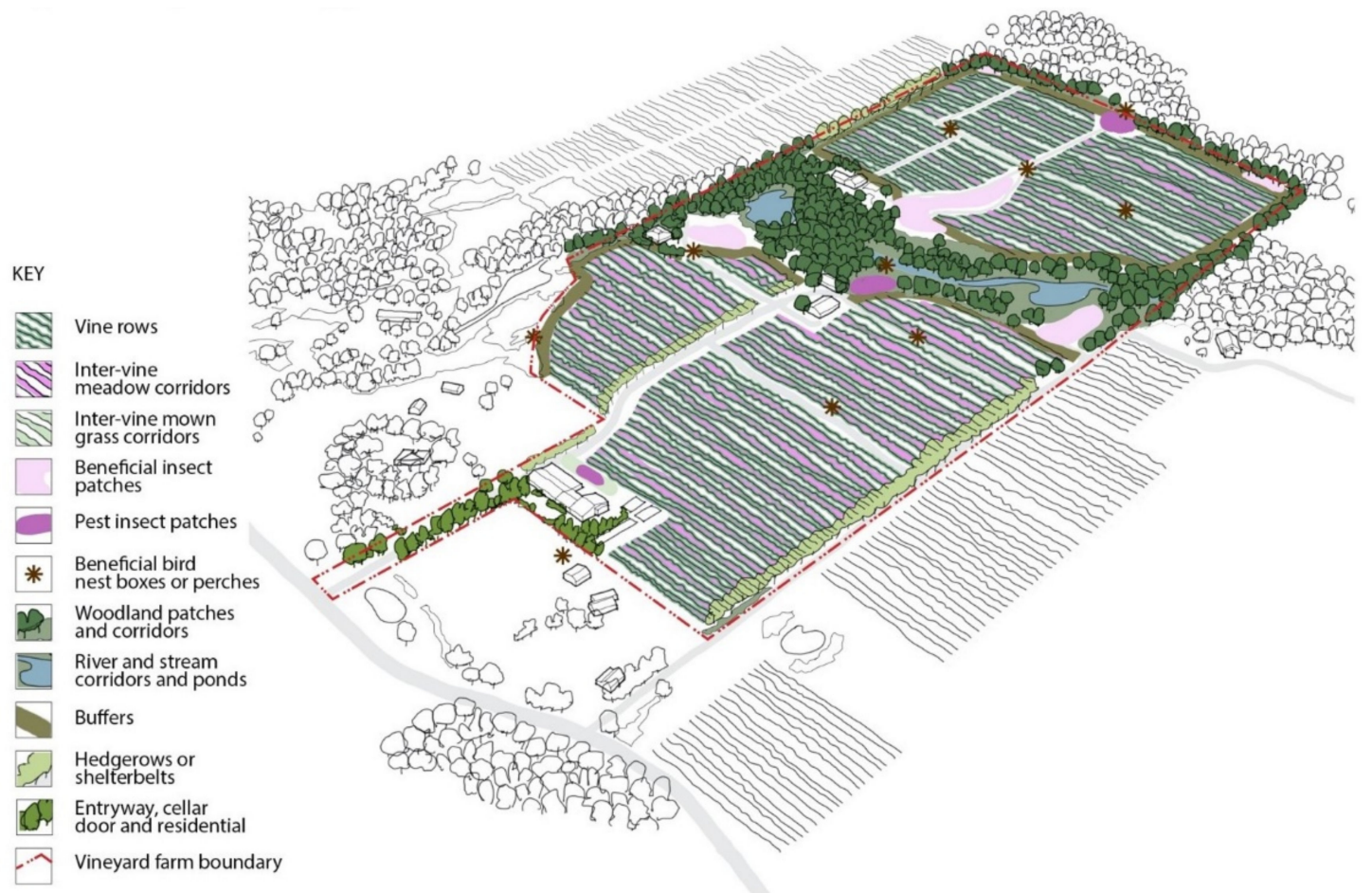

Figure 3. Integration of sharing and sparing green infrastructure systems across a vineyard farm providing multiple ecosystem services and functions.

\subsection{Other Production Systems}

Most interviewees indicated they were uninterested in implementing other production systems beyond grapes and wine, despite the argument in the literature that diversifying production systems can increase farm resilience in face of environmental and economic stochastic events [11]. For example, only one grower expressed concern of an increased risk of pest outbreaks within her region due to a loss of GI with continued agricultural development and climate change. This lack of concern may be a significant barrier to implementing biodiversity strategies, such as introducing other production systems, or GI, meant to increase landscape heterogeneity and therefore enhanced resilience.

Biodynamic farmers were the exception to the rule. They incorporated multiple systems, largely to reduce energy use, manage their wastes as resources, in addition to other 
environmental impacts associated with purchasing external inputs from conventionally designed farms. While carbon emission reductions have been demonstrated on biodynamic farms [13], it is unclear how resilient these farms are in response to environmental or economic stochastic events. Their self-reliance may help insulate them from shocks affecting other farm systems, as they are producing all vineyard system inputs themselves. However, community resilience following a stochastic event is known to increase with social capital and networks within communities [56], and these may not be encouraged between biodynamic farms and their neighbours. In contrast, many non-biodynamic interviewees mentioned positive relationships with neighbours (although also some negative), who provided them with system inputs they were not producing themselves. These relationships may increase their resiliency following environmental or economic stochastic events [56]. Both resilience strategies have merit and offer potentially complementary ways to achieve more resilient vineyard production systems.

\subsection{Enablers and Barriers to Implementation of Biodiversity Farming Strategies}

\subsubsection{Level of Awareness of, and Belief in, Ecosystem Services and Functions}

Growers most implemented GI types and other production systems, when they believed they provided valued services and functions. While value placed on GI types appeared to increase with the number of services and functions attributed to the GI (Table 3); of paramount importance was a belief in their production-related services. When growers believed production-related services missing, much less GI implementation appeared to occur-despite the existence of other valued benefits like nature conservation. For example, meadow cover crop corridors were most frequently implemented among all GI types because growers believed they provided multiple services, but most importantly, production-related services. Supporting studies likely helped to promote these beliefs among growers, an important enabler given that few growers are monitoring the effectiveness of their cover crops. For example, studies support the role of inter row cover crops as habitat for pest regulating organisms [33], as a way of altering soil fertility [31], increasing organic matter and soil moisture [29,30], suppressing competing weeds [30], as well as reducing soil erosion [29]. Importantly, these growers also believed cover crops ultimately improve the quality of their grapes and wine, a belief that maybe key to implementation if growers can effectively communicate to consumers the relationship between these environmentally beneficial practices and the quality of their wines [25].

Growers attributed fewer valued services or functions to sales-related GI. In general, there was a low level of awareness among growers of cellar door/winery vegetation and water systems and their services and functions. When prompted, growers said they appreciated their aesthetic and branding services, with a minority mentioning they provided habitat for bees. This relatively low awareness and value placed on these GI types may reflect the low number of studies demonstrating a strong relationship between them and improved marketing or sale of wine [57]. For example, patches of native vegetation were implemented in and around cellar doors within some New Zealand wineries, and designed to educate visitors about the use and value of native plant communities supported wildlife. These were promoted by funders as ways to improve regional green branding (and by extension wine sales) at cellar doors. However, studies indicated few economic benefits resulted from this GI. For example, cellar door visitors said these plantings were not factors in their decisions to purchase wine at cellar doors [58]. Further research is needed to identify and test GI designs in and around cellar doors, wineries, and across farms for their support for green branding and wine sales.

In terms of production systems, only Demeter biodynamic interviewees indicated they believed in, and valued, the services other production systems contributed to their farms. These systems were enabled by the services they provided in support of wine and grape production systems rather than by their contributions to farm income. Many nonbiodynamic farmers did not value, or attribute these services to, alternative production systems, and therefore did not implement them in a significant way on their farms. 


\subsubsection{Knowledge of Designing and Managing GI and Other Production Systems}

Grower knowledge of how to design and manage GI and alternative production system services and functions was also a key enabler for their implementation. For example, growers expressed sophisticated knowledge of production-related GI, such as cover crops, and this enabled their implementation relative to other GI types. Another study also demonstrated a high level of knowledge regarding cover crops among growers [47], revealing a wide variety of designs and management regimes depending on growing conditions. Despite this level of knowledge, growers indicated they were uncertain about whether their cover crops provided the services, and how to manage them, and this likely impeded their implementation among some growers. As interviewees indicated they were not monitoring the performance of their cover crops, there is a role to be played by researchers to assist in this regard to reduce this uncertainty and enhance GI implementation among growers.

Interviewees did not have much understanding of the design and/or management of either sales-related or nature-conservation related GI components, with some indicating they needed support from external experts in these areas. Yet, this understanding is vital if growers are to maximize their services and functions and minimize their disservices. In terms of nature conservation areas, it is particularly important to ensure the survival and recovery of the less than one percent of oak savanna community remaining in the region [49]. Most growers with oak savanna and woodlands were not attempting to restore or manage them beyond removing plants they considered undesirable, like Himalayan blackberry (Rubus armeniacus). In part, this may be due to a lack of interest among some growers; however, it may also be due to a lack of knowledge, and funding. More research is needed to arrive at effective GI design and management strategies in support of vineyard sales and branding (including at the regional scale), and of targeted species and vegetation communities of regional concern. However, achievement of these aims will require the participation of a wider group of stakeholders in decision making beyond just growers, including local and/or regional governments that have the required coarse scale perspective, expertise, and financial resources needed $[17,26]$.

\subsubsection{Certification Programme Requirements}

Certification policies requiring a type of GI (e.g., set asides for nature conservation or "ecological compensation") or other production systems (Demeter biodynamic certification) were also important GI enablers. Many growers said they valued being certified under these programmes as they allowed them to enter new markets, and/or wine price premiums [2,15], and therefore, were motivated to implement the required GI or production systems required by policies. Some interviewees argued aspects of these policies may also impede GI implementation, particularly of GI networks. They argued that criteria for identifying areas on farms qualifying for inclusion in set asides were too strict and arbitrary. They said the key criteria for inclusion was an area's lack of association with production (including sales and residential areas within farms), and not the area's support, or potential support, for indigenous biodiversity. Yet, studies indicate many types of seminatural $[10,37]$, croplands (e.g., vegetable gardens) and residential gardens [10], can play supporting roles in nature conservation in intensively developed landscapes. This restrictive policy is likely to discourage growers from designing and managing GI networks of GI components across farms in support of indigenous biodiversity, and of designing networks in support of multiple services, including the production and sales-related services more likely to get the GI implemented. Many studies have demonstrated that a variety of semi-natural vegetation types can support multiple ecosystem services beyond nature conservation, including water filtration [32], and pest regulation [10,37]. Further research is required to identify effective ways of designing and managing semi-natural GI types across farms to maximize not only their role in nature conservation, but in support of other services of interest to growers to encourage their implementation. 


\subsubsection{Availability of Land Incapable of Growing Quality Grapes}

A further enabler among growers for both GI and additional production system implementation was the availability of land incapable of producing quality grapes. Where this land was missing, growers indicated they were impeded from implementing GI, particularly that associated with a sparing nature conservation strategy. Growers with smaller vineyards argued all their land could produce quality grapes, so they had little remaining for alternative uses. On larger farms, more unproductive land was likely to be available; however, this was not guarantee that growers would implement either GI or another production system, particularly if growers did not value or associate sufficient services to these land uses.

\subsubsection{Availability of GI Backup Systems}

Many growers in this study indicated they still use synthetic pesticides or multiple treatments of (organic) copper to regulate pests. Growers face reduced risk of pest outbreaks under these integrated approaches. Continued use of these pesticides is likely a key enabler for meadow cover crop implementation as it reduces the risks associated with their failure. However, interviewees said they were concerned about the environmental and human health aspects of their continued use, including the use of copper promoted by the Organic certifier, and a concern shared by other growers [44]. Furthermore, growers were concerned their pesticide use significantly reduced the population sizes of beneficial organisms in proximity to grape rows. Studies indicate pest regulation services can be provided by cover crops, as well as a variety of semi-natural types of GI within and around vineyard farms [30,33-35]; however, these components need to be designed as networks across farms to ensure they work together in support of robust populations of targeted species. As noted by one grower, providing additional habitat patches for beneficial organisms within travel distance of vine rows, but outside of pesticide spray zones, can increase the chance of population survival. However, further research is required to identify effective networks in support of valued production related services, like pest regulation, within intensive agricultural systems, such as vineyards.

\subsubsection{Risk of Regional Pest Outbreaks}

Despite the uncertainties expressed by growers regarding GI services, such as pest regulation, and therefore the continued use of synthetic system inputs, growers still indicated there was risk associated with the use of GI. However, they were willing to accept the risk of their potential failure because they had few pests in their region. This perceived low risk may have been a key enabler for GI implementation among these growers. However, growers in other regions may face more serious pest problems and therefore the risk of relying on GI, whose performance is uncertain, is higher. Further research is required to needed to identify what determines regional vulnerability to pest outbreaks, including the level of landscape heterogeneity from GI and multiple production systems, to develop effective regional strategies for minimizing the risks associated with environmental events, such as pest outbreaks, to acceptable levels among growers.

\subsubsection{Wine Prices}

The premium price of grower wines was also an enabler for implementing GI as growers who owned land incapable of growing quality grapes suggested they did not have to fully develop their land to make a sufficient profit. Other studies have also demonstrated this enabler for growers, at least in terms of cover crop establishment [47].

\subsubsection{Grower Ethics}

Most growers indicated that GI consisting of oak savanna, woodland, buffers, and hedgerows, provided mostly nature conservation and few other services of direct benefit to them. For these components, key implementation enablers were grower ethics and values supporting nature conservation and cultural heritage. They said they supported 
their conservation because it was the right thing to do and indicated these areas of their farms reflected their identity and cultural heritage. In evidence of this, some growers said they would retain their nature conservation-related GI even where it occupied land capable of growing quality grapes. This enabler is supported by studies that demonstrate the importance of farmer attitudes and norms in the uptake of agricultural innovations $[59,60]$.

\section{Conclusions}

Growers need to pursue both efficiency/substitution and biodiversity strategies to improve the environmental performance of conventionally designed vineyard farms. However, few studies explore the implementation of biodiversity strategies among winegrowers. In this research, we helped fill this gap by surveying the strategies of certified growers in the Willamette Valley, Oregon, as potential early adopters of innovative strategies. Identifying new and effective strategies is vital to develop effective ways to harness the power of science in support of their implementation.

Findings indicate growers are implementing multiple types of GI within their farms that provide a range of ecosystem services, ranging from support for grape production, to enhancement of wine sales and branding, to nature conservation. The addition of other production systems on farms received less support among growers but was important for biodynamic winegrowers to minimize their production inputs and support their unique branding. Both GI and multiple production system strategies are focused on enhancing sales/branding, and particularly, grape production services within vineyards. GI that provides production-related services is well supported in the literature; however, more research is needed on GI that provides other valued services related to sales/branding, nature conservation, and particularly resiliency, to identify GI that provides multiple services across farms of value to growers.

This research also uncovers much needed information about the spatial design of GI, showing that it is being designed at three spatial scales: (1) Within vine blocks and sales blocks, (2) between vine blocks, and between vine blocks and sales blocks, and (3) across vineyard farms. GI is largely being integrated into production systems at the fine scale (following a land sharing design strategy). However, at intermediate and farm-wide scales, growers are pursuing a two-fold sharing/sparing strategy, integrating some GI elements into production systems, and at the same time, setting some areas aside for nature conservation. Emphasis placed on sharing strategies by growers reflects the importance they place on production and sales/branding; however, the sparing strategy in support of nature conservation at coarser spatial scales may be important for supporting some species or vegetation communities of conservation concern as some require larger and more connected networks and less disturbance from intensive production systems.

Despite this seemingly sophisticated design approach to implementing GI, growers are following these strategies inadvertently, as they are still largely designing and managing their GI as individual components and are focusing most of their attention on vineyard block components, such as meadow cover crops. To improve GI services and functions within these vineyards, growers need to design their GI as networks and integrate them across their farms, and not just within their production areas. Furthermore, growers might consider working with neighbours, and other stakeholders in the landscape, such as local and regional governments, to accomplish design objectives requiring coarser spatial scale networks, like the restoration of high surface water quality within catchments, conservation of species and communities of concern and support of regional branding. While eight key enablers for encouraging implementation among growers were identified, many barriers to implementation continue to be present, and these need to be overcome for widespread biodiversity strategy implementation, particularly within wine regions where these enablers are missing.

Author Contributions: Conceptualization, W.M.; Methodology, W.M. and A.W., Data curation and formal analysis, W.M., Writing-original draft preparation, W.M., Writing-review and editing, W.M. and A.W. All authors have read and agreed to the published version of the manuscript. 
Funding: This research received no external funding.

Institutional Review Board Statement: The study was conducted according to the guidelines of the Lincoln University Human Ethics Committee.

Informed Consent Statement: Informed consent was obtained from all subjects involved in the study.

Data Availability Statement: Data other than presented in this study are not publicly available due to ethical restrictions.

Acknowledgments: We would like to thank Chris Serra and Brighid O'Keane from LIVE, Mark Chien from the Oregon Wine Research Institute, in addition to Marcus Robinson and Suphicha Muangsri from Lincoln University for their assistance.

Conflicts of Interest: The authors declare no conflict of interest.

\section{References}

1. Altieri, M.; Nicholls, C. The simplification of traditional vineyard-based agroforests in Northwestern Portugal: Some ecological implications. Agrofor. Syst. 2002, 56, 185-191. [CrossRef]

2. Viers, J.H.; Williams, J.N.; Nicholas, K.A.; Barbosa, O.; Kotzé, I.; Spence, L.; Reynolds, M. Vinecology: Pairing wine with nature. Conserv. Lett. 2013, 6, 287-299. [CrossRef]

3. Orre-Gordon, S.; Jacometti, M.; Tomkins, J.-M.; Wratten, S.D. Viticulture can be modified to provide multiple ecosystem services. In Ecosystem Services in Agricultural and Urban Landscapes; Wratten, S., Sandhu, R., Cullen, R., Constanza, R., Eds.; Wiley-Blackwell: Chichester, UK, 2013.

4. Herrero-Hernández, E.; Rodríguez-Cruz, M.S.; Pose-Juan, E.; Sánchez-González, S.; Andrades, M.S.; Sánchez-Martín, M.J. Seasonal distribution of herbicide and insecticide residues in the water resources of the vineyard region of La Rioja (Spain). Sci. Total Environ. 2017, 609, 161-171. [CrossRef] [PubMed]

5. García-Ruiz, J.M. The effects of land uses on soil erosion in Spain: A review. Catena 2010, 81, 1-11. [CrossRef]

6. Komarek, M.; Cadkova, E.; Chrastny, V.; Bordas, F.; Bollinger, J.C. Contamination of vineyard soils with fungicides: A review of environmental and toxicological aspects. Environ. Int. 2010, 36, 138-151. [CrossRef] [PubMed]

7. Point, E.; Tyedmers, P.; Naugler, C. Life cycle environmental impacts of wine production and consumption in Nova Scotia, Canada. J. Clean. Prod. 2012, 27, 11-20. [CrossRef]

8. Thomson, L.J.; Hoffmann, A.A. Field validation of laboratory derived IOBC toxicity ratings for natural enemies in commercial vineyards. Biol. Control 2006, 39, 507-515. [CrossRef]

9. Briones, M.J.; Schmidt, O. Conventional tillage decreases the abundance and biomass of earthworms and alters their community structure in a global meta-analysis. Glob. Chang. Biol. 2017, 23, 4396-4419. [CrossRef]

10. Assendri, G.; Bogliani, G.; Pedrini, P.; Brambilla, M. Diversity in the monotony? Habitat traits and management practices shape avian communities in intensive vineyards. Agric. Ecosyst. Environ. 2016, 223, 250-260. [CrossRef]

11. Nicholas, K.A.; Durham, W.H. Farm-scale adaptation and vulnerability to environmental stresses: Insights from winegrowing in Northern California. Glob. Environ. Chang. 2012, 22, 483-494. [CrossRef]

12. Gabzdylova, B.; Raffensperger, J.F.; Castka, P. Sustainability in the New Zealand wine industry: Drivers, stakeholders and practices. J. Clean. Prod. 2009, 17, 992-998. [CrossRef]

13. Villanueva-Rey, P.; Vazquez-Rowe, I.; Moreira, M.T.; Feijoo, G. Comparative life cycle assessment in the wine sector: Biodynamic vs. conventional activities in NW Spain. J. Clean. Prod. 2014, 65, 330-341. [CrossRef]

14. Padel, S. Conversion to Organic Farming: A typical example of the diffusion of an innovation? Sociol. Rural. 2002, 41, 40-61. [CrossRef]

15. Loveless, K.; Mueller, S.; Lockshin, L.; Corsi, A. The relative importance of sustainability, quality control standards and traceability for wine consumers: A cross-national segmentation. In Proceedings of the 6th AWBR International Conference, Bordeaux, France, 9-10 June 2011.

16. Ying, G.G.; Williams, B. Herbicide residues in grapes and wine. J. Environ. Sci. Health Part B 1999, 34, 397-411. [CrossRef]

17. Duru, M.; Therond, O.; Tares, M. Designing agroecological transitions: A review. Agron. Sustain. Dev. 2015, 35, 1237-1257. [CrossRef]

18. Szolnoki, G. A cross-national comparison of sustainability in the wine industry. J. Clean. Prod. 2013, 53, 243-251. [CrossRef]

19. Demeter-USA.org. The Biodynamic Wine-FAQ. Available online: https://www.demeter.de/verbraucher/landwirtschaft/ weinbau/weltweit/faq (accessed on 20 November 2020).

20. Winter, S.; Bauer, T.; Strauss, P.; Kratschmer, S.; Paredes, D.; Popescu, D.; Landa, B.; Guzman, G.; Gomez, J.; Guernion, M.; et al. Effects of vegetation management intensity on biodiversity and ecosystem services in vineyards: A meta-analysis. J. Appl. Ecol. 2017, 55, 2484-2495. [CrossRef]

21. Okur, N.; Altindisli, A.; Cengel, M.; Gocmez, S.; Kayikcioglu, H.H. Mircrobial biomass and enzyme activity in vineyard soils under organic and conventional farming systems. Turk. J. Agric. For. 2008, 33, 413-423. 
22. Probst, B.; Schuler, C.; Joergensen, R.G. Vineyard soils under organic and conventional management-Microbial biomass and activity indices and their relation to soil chemical properties. Biol. Fertil. Soils 2007, 44, 443-450. [CrossRef]

23. Kavargiris, S.E.; Mamolos, A.P.; Tsatsarelis, C.A.; Nikolaidou, A.E.; Kalburtji, K.L. Energy resources' utilization in organic and conventional vineyards: Energy flow, greenhouse gas emissions and biofuel production. Biomass Bioenergy 2009, 33, $1239-1250$. [CrossRef]

24. Garini, C.S.; Vanwindekens, F.; Scholberg, J.M.S.; Wezel, A.; Groot, J.C.J. Drivers of adoption of agroecological practices for winegrowers and influence from policies in the province of Trento, Italy. Land Use Policy 2017, 68, 200-211. [CrossRef]

25. Siepmann, L.; Nicholas, K.A. German winegrowers' motives and barriers to convert to organic farming. Sustainability $2018,10,4215$. [CrossRef]

26. Marsden, T. Towards a real sustainable agri-food security and food policy: Beyond the ecological fallacies? Political Q. 2012, 83, 139-145. [CrossRef]

27. Kremen, C. Managing ecosystem services: What do we need to know about their ecology? Ecol. Lett. 2005, 8, 468-479. [CrossRef]

28. Tzoulas, K.; Korpela, K.; Venn, S.; Yli-Pelkonen, V.; Kazmierczak, A.; Niemela, J.; James, P. Promoting ecosystem and human health in urban areas using GIS: A literature review. Landsc. Urban Plan. 2007, 81, 167-178. [CrossRef]

29. Ruiz-Colmenero, M.; Bienes, R.; Eldridge, D.J.; Marques, M.J. Vegetation cover reduces erosion and enhances soil organic carbon in a vineyard in the central Spain. Catena 2013, 104, 153-160. [CrossRef]

30. Shields, M.W.; Tompkins, J.; Saville, D.J.; Meurk, C.D.; Wratten, S. Potential ecosystem service delivery by endemic plants in New Zealand vineyards: Successes and prospects. PeerJ 2016, 4, e2042. [CrossRef]

31. Pérez-Álvarez, E.P.; Garde-Cerdán, T.; Santamaría, P.; García-Escudero, E.; Peregrina, F. Influence of two different cover crops on soil N availability, N nutritional status, and grape yeast-assimilable N (YAN) in a cv. Tempranillo vineyard. Plant Soil 2015, 390, 143-156. [CrossRef]

32. Novara, A.; Gristina, L.; Guaitoli, F.; Santoro, A.; Cerda, A. Managing soil nitrate with cover crops and buffer strips in Sicilian vineyards. Solid Earth 2013, 4, 255-262. [CrossRef]

33. Danne, A.; Thomson, L.J.; Sharley, D.J.; Penfold, C.M.; Hoffmann, A.A. Effects of native grass cover crops on beneficial and pest invertebrates in Australian vineyards. Environ. Entomol. 2010, 39, 970-978. [CrossRef]

34. Papura, D.; Roux, P.; Joubard, B.; Razafimbola, L.; Fabreguettes, O.; Delbac, L.; Rusch, A. Predation of grape berry moths by harvestmen depends on landscape context. Biol. Control 2020, 150, 104358. [CrossRef]

35. Thomson, L.J.; Hoffmann, A.A. Vegetation increases the abundance of natural enemies in vineyards. Biol. Control 2009, 49, 259-269. [CrossRef]

36. Altieri, M.A.; Ponti, L.; Nicholls, C.I. Manipulating vineyard biodiversity for improved insect pest management: Case studies from northern California. Int. J. Biodivers. Sci. Manag. 2005, 1, 191-203. [CrossRef]

37. Kratschmer, S.; Pachinger, B.; Schwantzer, M.; Paredes, D.; Guernion, M.; Burel, F.; Nicolai, A.; Strauss, P.; Bauer, T.; Kriechbaum, M.; et al. Tillage intensity or landscape features: What matters most for wild bee diversity in vineyards? Agric. Ecosyst. Environ. 2018, 266, 142-152. [CrossRef]

38. Eplényi, O. Viticultural landscape patterns-Embedding contemporary wineries into the landscape site. Sci. J. Latv. Univ. Agric. Landsc. Archit. Art 2017, 10, 7-14.

39. Fischer, J.; Abson, D.J.; Butsic, V.; Chappell, M.J.; Ekroos, J.; Hanspach, J.; Kuemmerle, T.; Smith, H.G.; Von Wehrden, H. Land sparing versus land sharing: Moving forward. Conserv. Lett. 2014, 7, 149-157. [CrossRef]

40. Steel, Z.L.; Steel, A.E.; Williams, J.N.; Viers, J.H.; Marquet, P.A.; Barbosa, O. Patterns of bird diversity and habitat use in mixed vineyard-matorral landscapes of Central Chile. Ecol. Indic. 2017, 73, 345-357. [CrossRef]

41. Forman, R.T.T. Land Mosaics: The Ecology of Landscapes and Regions; Cambridge University Press: Cambridge, NY, USA, 2002.

42. Scariot, A. Land sparing or land sharing: The missing link. Front. Ecol. Environ. 2013, 11, 177-178. [CrossRef]

43. Winkler, K.J.; Viers, J.H.; Nicholas, K.A. Assessing ecosystem services and multi-functionality for vineyard systems. Front. Environ. Sci. 2017, 5, 15. [CrossRef]

44. Marques, M.J.; Bienes, R.; Cuadrado, J.; Ruiz-Colmenero, M.; Barbero-Sierra, C.; Velasco, A. Analysing perceptions attitudes and responses of winegrowers about sustainable land management in central Spain. Land Degrad. Dev. 2015, 26, 458-467. [CrossRef]

45. Forbes, S.L.; Cullen, R.; Grout, R. Adoption of environmental innovations: Analysis from the Waipara wine industry. Wine Econ. Policy 2013, 2, 11-18. [CrossRef]

46. Rebekka Schütte, R.; Bergmann, H. The attitudes of French and Spanish winegrowers towards the use of cover crops in vineyards J. Wine Res. 2019, 30, 107-121. [CrossRef]

47. Fernández-Mena, H.; Frey, H.; Celette, F.; Garcia, L.; Barkaoui, K.; Hossard, L.; Naulleau, A.; Métral, R.; Gary, C.; Metay, A. Spatial and temporal diversity of service plant management strategies across vineyards in the south of France. Analysis through the Coverage Index. Eur. J. Agron. 2021, 123, 126191. [CrossRef]

48. Stake, R.E. The Art of Case Study Research; Sage: Thousand Oaks, CA, USA, 1995.

49. USDI Bureau of Land Management, Salem District. A Landowner's Guide for Restoring and Managing Oregon White Oak Habitats; USDI Bureau of Land Management, Salem District: Grand Junction, CO, USA, 2004. [CrossRef]

50. Willamette Valley Wine. Sustainable Winegrowing in Oregon. Available online: https://willamettewines.com/about-the-valley/ sustainability/ (accessed on 20 November 2020).

51. LIVE Certified Organization. Available online: https:/ /livecertified.org/ (accessed on 20 November 2020). 
52. Seawright, J.; Gerring, J. Case selection techniques in case study research: A menu of qualitative and quantitative options. Political Res. Q. 2008, 61, 294-308. [CrossRef]

53. Townsend, R.F.; Kirsten, J.; Vink, N. Farm size, productivity and returns to scale in agriculture revisited: A case study of wine producers in South Africa. Agric. Econ. 1998, 19, 175-180. [CrossRef]

54. Frankfort-Nachmias, C.; Nachmias, D.; DeWaard, J. Research Methods in the Social Sciences, 8th ed.; NY Worth Publishers: New York, NY, USA, 2015.

55. McWilliam, W.; Gregorini, P. Re-designing New Zealand's productivist livestock production systems: Current strategies and next steps. N. Zeal. J. Anim. Sci. Prod. 2018, 78, 132-136.

56. Aldrich, D.P.; Meyer, M.A. Social capital and community resilience. Am. Behav. Sci. 2014, 59, 254-269. [CrossRef]

57. Forbes, S.L.; De Silva, T. Analysis of environmental management systems in New Zealand wineries. Int. J. Wine Bus. Res. 2012, 24, 98-114. [CrossRef]

58. Fountain, J.M.; Tompkins, J. The potential of wine tourism experiences to impart knowledge of sustainable practices: The case of the Greening Waipara biodiversity trails. In Proceedings of the 6th AWBR International Conference, Bordeaux, France, 9-10 June 2011.

59. Marshall, R.; Cordano, M.; Silverman, M. Exploring individual and institutional drivers of proactive environmentalism in the US wine industry. Bus. Strategy Environ. 2005, 14, 92-109. [CrossRef]

60. Cordano, M.; Marshall, R.S.; Silverman, M. How do Small and Medium Enterprises Go “Green"? A Study of Environmental Management Programs in the U.S. Wine Industry. J. Bus. Ethics 2010, 92, 463-478. [CrossRef] 